\title{
Sustainable Architecture for Communities Affected by Environmental Disasters and the Case of Mariana, the Largest Environmental Accident in Brazil
}

\author{
Maria Fernanda Britto Neves ${ }^{1}$, Deyse Maimone dos Santos ${ }^{2}$, José Carlos Loureiro ${ }^{3}$ \\ ${ }^{1}$ International Environmental Law and Architecture and Urbanism Course, Catholic University of Santos, Santos, Brazil \\ ${ }^{2}$ Architecture and Urbanism Course, Catholic University of Santos, Santos, Brazil \\ ${ }^{3}$ International Environmental Law, Catholic University of Santos, Santos, Brazil
}

Email address:

fbrittoneves@uol.com.br (M. F. B. Neves),dmaionester@gmail.com (D. M. d. Santos), zeloureiro33@gmail.com (J. C. Loureiro)

\section{To cite this article:}

Maria Fernanda Britto Neves, Deyse Maimone dos Santos, José Carlos Loureiro. Sustainable Architecture for Communities Affected by Environmental Disasters and the Case of Mariana, the Largest Environmental Accident in Brazil. International Journal of Environmental Monitoring and Analysis. Vol. 5, No. 4, 2017, pp. 116-122. doi: 10.11648/j.ijema.20170504.14

Received: June 8, 2017; Accepted: August 4, 2017; Published: August 14, 2017

\begin{abstract}
This article analyzes the largest environmental accident in Brazil, the rupture of the tailings dam at Samarco, in Fundão, Bento Rodrigues district, in the Mariana region of the State of Minas Gerais, Brazil. The study contemplates historical and socioenvironmental aspects. For the understanding and analysis, bibliographical and digital surveys were carried out, as well as exploratory research, with site visits and interviews with the affected population. Far from a complete and satisfactory solution, one can understand the size of the accident, its causes, effects and mitigation measures, as well as a perspective of awareness of the accident by the resident population. The study seeks to evaluate possible housing alternatives for those who have lost their homes and, with them, everything they have: their own life stories.
\end{abstract}

Keywords: Environmental Accidents, Affected Population, Architecture for Refugees

\section{Introduction}

The accelerated degradation of the global environment is forcing millions to move from their places of origin. Most of these people displaced for environmental reasons are poor, and are already surpassing the number of political refugees.

According to the IPCC Report of 2014:

"Warming of the climate system is unequivocal, and since the $1950 \mathrm{~s}$, many of the observed changes are unprecedented over decades to millennia. The atmosphere and ocean have warmed, the amounts of snow and ice have diminished, and sea level has risen". [7]

All these changes have displaced people, forcing them to leave their places of origin to try to survive in other territories.

The intimate connection between the environment and population mobility became evident, not in the positive sense that people migrated to achieve a better quality of life, but in the negative sense: they emigrated because they were forced to [10].

Considering the aforementioned context of environmentally displaced people, this paper intends to present the specific case of the environmental disaster of Mariana and its impacts on the affected population.

The rupture of the Fundão dam, in Bento Rodrigues district, near Mariana, State of Minas Gerais, in the Southeastern region of Brazil is considered the greatest environmental disaster in Brazil and represents a milestone in which the ineffectiveness of environmental agents of prevention, mitigation and damage repair can be observed.

This study is based on five points:

(1) the historical and geographical contextualization of the district of Bento Rodrigues;

(2) the description of the disaster, including damage caused by the accident, the ineffectiveness of the

(3) prevention and preliminary reports of actions taken to mitigate the problem;

(4) sociological aspects of the accident, seeking to raise its socio-environmental effects, the assimilation of the accident by the population affected and their awareness of risk; 
(5) getting closer with the local community in order to understand their wishes and to raise the possible alternatives regarding the reconstruction of their houses and the recovery of their life stories;

(6) finally, looking at refugee camps in other parts of the world, reflecting on the possible contributions of town planning architects to these communities.

\section{Main Body}

\subsection{Historical and Geographical Contextualization}

Founded during the gold mining cycle in the 18th century, Bento Rodrigues is a district of Mariana, a projected city that is born on the banks of Ribeirão Nossa Senhora do Carmo and has its strategic function determined by gold, precious stones and ore.

Bento Rodrigues and Mariana are delimited by their mining activity and located approximately $120 \mathrm{~km}$ away from Belo Horizonte, capital of Minas Gerais. Before the accident the district had a population of 600 inhabitants, most of whom depended on the mining activity of companies such as Samarco / Vale / BHP Billinton.

\subsection{The Accident}

Samarco Mineração S. A, which operates in the ore exploration, is maintained by the Brazilian company Vale S. A. and the Anglo-Australian BHP Billiton, considered in 2015 as giants of the mining sector. Their dams are used to store water or iron ore tailings [11].

In the afternoon of November 5,2015 , the Fundão dam broke, sending 34 million cubic meters of mud into the environment, resulting from the iron ore production by the mining company, as shown in Figure 1 [2].

$663 \mathrm{~km}$ of rivers and streams were affected and 1,469 hectares of vegetation were compromised, in addition to 207 buildings that ended up buried, of the 251 existing, only in the district of Bento Rodrigues.

The flood of tailings quickly spread throughout the region, leaving more than 600 homeless families and 17 people dead.

In a matter of hours the mud reached the river Doce, whose basin is the largest in the Southeast of the Country, with an area of $82,646 \mathrm{~km}^{2}$, equivalent to twice the State of Rio de Janeiro.

The disaster today is considered one of the largest in Brazil. According to Bowker Associates \& Research in Public Interest, a North American risk management consultancy related to heavy construction, in partnership with the geophysicist David Chambers, it is the largest in the world, not in deaths, but in volume of mobilized mud and distance traveled.

The increase in turbidity of the water (and not a supposed contamination), caused the death of thousands of fish and other animals. According to the Brazilian Institute for the Environment and Renewable Natural Resources - IBAMA, out of more than 80 species of fish identified as native before the tragedy, 11 are now classified as endangered, and 12 species were endemic in the region [6].

The water supply to city dwellers supplied by the region's rivers had to be temporarily interrupted and resumed days later, when reports from government technical bodies ruled out contamination of water by toxic materials.

The mud advanced the river with great speed, reaching the neighboring State of Espírito Santo in less than five days and, on November 21, reached the sea in Linhares, covering $600 \mathrm{~km}$, as shown in Figure 1 [3] and Figure 2 [8].

Containment blocks were positioned at the mouth of the river to control the environmental impact of mud coming into the sea.

Most of the losses were due to lack of risk containment and communication projects. There was no alert mechanism installed, the population was its own siren. Many were advised by telephone at the time of the disaster;

In some cases, Samarco workers went to warn them in person. The event was so unexpected that many thought it was a bluff.

The proportion of the disaster has raised questions about the possibility of an accident or negligence, dividing responsibilities between dam owners and government agencies.

Only five accidents with tailings dams have exceeded 10 million cubic meters until today, according to the US consultancy Bowkers Associates, according to Graphic 1 [3].

Bento Rodrigues is now situated between two newly created dams, as a consequence of the disaster.

Closed by Samarco, the city is open on certain days so former residents can visit. The place still has difficult access and nobody knows what will happen to it.

As for the recovery of the environment, there is some indication that the forest and flora are already beginning to resurface in the area.

\subsection{Socio-environmental Aspect of the Disaster}

Under the sociological aspect of the disaster of Bento Rodrigues, it is necessary to consider that this disaster is characterized by what precedes it and what happens after it. Not just the moment of the incident nor when it is in the news.

The disaster is responsible as a disturbance of a social dynamic in which, rapid resignation and creativity are required through measures to be taken for the poor communities.

According to Valencio [12], the social life of a person is based on a trinomial: family, housing and work. In this way the environmental refugee does not only lose what supports him financially but he also loses the necessary bonds in social relations.

In the disaster, it is not houses that must be restored first, it is the interlocution with the affected, so that they can translate in their own terms the understanding of what they know as rehabilitation and reconstruction. The Work Plan, which accompanies the damage assessment, generally contains mandatory requirements and reflects its focus on civil construction works that favor access to extraordinary resources [12]. 
According to the National Civil Defense Policy, a disaster can be defined as "the result of adverse events, whether natural or man-made, on a vulnerable ecosystem, causing human, material and environmental damage, and consequently economic and social damage."

In this way, what would be the justification for the slowness and the inefficiency in accident prevention, especially in a region already known as high risk?

The inconsistency of the official information of the National Secretariat of Civil Defense (SINDEC) is indicated by the lack and omission of accurate information by the Government bodies and the companies that caused the disaster. In addition, transparency can be questioned, due to the lack of accessibility to information, thus preventing its own control and leading to slowness in disclosing the facts [12].

Still in the words of Valencio [12], "bureaucratic temporality does not match the temporality of everyday life".

\subsection{Approaching the Mariana Community}

Where did the habitants of Bento Rodrigues go? In a visit to the homeless community, it is possible to see that, today, the former residents are located in Mariana, a medium-sized city with a district of 600 inhabitants.

Adapting their lives has not been an easy task. The inhabitants live in houses rented by the company Samarco, but suffer from the inconvenience of living in a much larger and unknown place, both in scale and social structures.

As a way to try keeping the discussion alive and making improvements, a newspaper called "A Sirene" (The Siren) was produced, as a way of criticizing the fact that no one raised the alarm sounds at the moment of disaster.

With chaos unleashed, it became necessary to think in what way things could be remediated as a way to hinder, rehabilitate and even recover the Bento Rodrigues region.

During many meetings, a project to reconstruct Bento Rodrigues was conceived.

This project is located in Lavoura, district of Camargos, in a total area of 2.232 hectares and an acquisition area of 350 hectares.

Being well-situated was a pre-requisite, since Lavoura is close to former Bento Rodrigues, with accessible public transportation, substantial hydric resources and closeness to water springs; it also has as rich soil for planting and raising animals.

The engineer Álvaro Pereira, leader of the Fundação Renova's reconstruction programs, guaranteed that there would certainly be changes, but also that the entire project was developed according to the directions of the older residents of Bento Rodrigues.

The reconstruction project of Bento Rodrigues is included in the actions that will be carried out by Samarco to mitigate the impacts of the disaster in the cities of Minas Gerais and Espírito Santo.

Examples of some of the actions taken:

(1) $100 \%$ of 800 hectares in the rivers Doce, Carmo and Gualaxo were revegetated;

(2) In Mariana and Barra Longa, all schools affected were reformed and $100 \%$ of students followed the regular school year of 2016 ;

(3) Houses and commercial establishments are being restored;

(4) The reconstruction program hired healthcare professionals (doctors, nurses, psychologists, social work assistants, dentists, physiotherapists, among others). They also bought material to help people in the affected areas;

(5) 200 rural properties were supplied with silage and plantations, as well as veterinary technical support and equipment;

(6) $134 \mathrm{~km}$ of fences were erected on rural properties;

(7) The affected communities, as well as fishermen and other river dwellers in Minas Gerais and Espírito Santo, have already received about 6,000 emergency financial aid cards.

(8) Three dams to contain sediments were constructed, so that these sediments are not carried by the rain and streams in the Fundão valley;

(9) More than 39,000 reports were issued by laboratories responsible for monitoring water and sediments, based on an investigation of more than 550 thousand analyses. Current results show that the Rio Doce river's water quality is similar to the standards observed in 2010;

(10) The water supply was reestablished in all cities impacted by the turbidity plume;

(11) Workers started the construction of two water mains in Colatina (ES); they also dug artesian wells in Colatina and Regência (ES);

(12) The construction of an alternative water collection system was completed, as well as the construction of an alternative raw water intake, which should only be used in case of emergency, according to the procedure formalized with the local environmental agency [9].

As a result of sudden changes, people's social life, based on the trinomial discussed by Valencio [12] - family, housing and work - is deeply affected. How is their future going to be?

Many people are waiting for the new Bento Rodrigues. Nowadays, it is being built on a terrain chosen by them. It will also have the same road system and equipment from the old Bento Rodrigues. The photos taken by the author Deyse Maimone dos Santos are an evidence that little was made to improve the citizens' situation, as shown by Figures 4 and 5 .

Were the actions taken the best measures possible for the Bento Rodrigues community?

Many answers will come only in the long run, when the effects will be felt, far from the environment of loss and emergency. The immediate answer today is represented by three verbs: to prevent, to plan and to mitigate.

To prevent, so that the accident does not occur again; to plan and evaluate what can be done if the disaster occurs. To mitigate and minimize damage, always considering the social, environmental and economic context. 


\subsection{Contributions from Urbanist Architects: Challenges and Opportunities}

Emergency brings about loss, feared by many. Where do favelas, stilts and slums come from, if not from a state of loss and emergency?

After an environmental disaster and habitat loss, even if it is not total, it is coherent to think of the refugee's ambience as a proto-city.

In the proto-city, pertinent and valuable elements could be retrieved, in a way that the community would assess their loss and discover possible solutions even to preexistent problems in their former city.

This could be translated as a framework, one which the residents would assume and adapt locally, culturally and environmentally, occupying space in a proper way.

From the framework comes its structure. Everything that is categorized as infrastructure would become an over-structure, exposed in such a way that its sustainable process is considered as a precedent of environmental education.

Before thinking about housing, it is coherent to think of all infrastructure that makes a house exist and coexist with the prevailing and emergency ecosystem.

The possibility of using the plateau that emerges from the soil allows the project to develop an adaptability for any type of topography.

Every environmental system becomes visible to generate an understanding in the community. It is from environmental understanding and education that society becomes more aware of the process that is often put as hidden in infrastructure. A concealed infrastructure causes non-awareness and lack of interest [4].

\subsubsection{Contributions from Urbanist Architects: Challenges and Opportunities}

Using the soil under their feet, the organization Pilosio Building Peace, together with the architects Pouya Khazaeli and Cameron Sinclair, developed the RE: BUILD project, a constructive system that allows the building of safe and comfortable structures in refugee camps.

The system allows the construction of high-quality temporary buildings using panels made from scaffolds and metal screens, that are, then, assembled and filled with gravel, sand or earth, creating well-insulated and low-cost indoor environments [1].

The structure can be used in hospitals, housing and other types of building. It will be described here the experience of the construction of two schools built with this system in Jordan, as illustrated by Figure 6 [1].

According to the architects, it is very important to build schools for these children, because they need not only education, but also a safe place to grow soundly and do their daily activities.

The project developed a basic structure for schools in refugee camps that combines natural elements, such as sand; building elements such as scaffold tubes, and the labor of refugees themselves [1].

The contribution of refugees in setting up these structures gives them the feeling that they are again in charge of their own destinies. The importance of the architect to use local labor and to understand the reality of the population is highly valued by Cameron Sinclair and his team.

A team of ten workers, without any prior knowledge of construction, is able to assemble a $16 \times 16$ meter structure in two weeks, under the supervision of a Pilosio Building Peace technician.

The use of sand, the best natural insulation and typical element of Syrian culture, makes the construction quite economic.

The idea is to directly use the soil "under your feet" as a building material. In this case, this occurs simply by filling the inner space of the walls with sand.

The structure does not depend on the existence of electricity or water at the site to be built [1].

The technical file of the school for the refugee camp [1]:

Location: Za'atari Refugee Camp, Jordan

Construction: Pilosio Peace Building and Syrian refugees from the Za'atari Refugee Camp

Responsible architect: Relief International Sponsored by: JHCO - Jordan Hashemite Charity Organization

Designers: Cameron Sinclair and Pouya Khazaeli

Team: Luca Drigani, Pouya Khazaeli, Dario Roustayan and Cameron Sinclair

Total cost: $€ 30.00$ Euros

Dimensions: $16 \mathrm{~m} \mathrm{x} 16 \mathrm{~m}$

\subsubsection{Will the Homeless Camps Be the Cities of Tomorrow?}

Between 2014 and 2015, some 4.8 million Syrians fled a war-ravaged country to seek shelter and a new chance to live in countries like Turkey, Greece and others in Europe [5].

The number increases to 19 million when refugees from Afghanistan, Iraq, Somalia, Nigeria and other countries in critical situations are included.

Without job offers or housing to these immigrants, receiving countries have closed their borders and established huge refugee camps in isolated areas where whole families settle in precarious conditions, not knowing if they will ever leave.

For Kilian Kleinschmidt, who worked at the UN for 25 years in the area of humanitarian aid for refugees, governments should stop thinking of the camps as temporary places. For him, these are the cities of tomorrow. The average time for a camp today is 17 years. This is a generation.

According to Kleinschmidt, the lack of willingness of governments to recognize that those camps are permanent throughout the world means that living conditions in these areas are becoming increasingly precarious and insecure, since there is no concern about investing in infrastructure [5]. 


\section{Details}

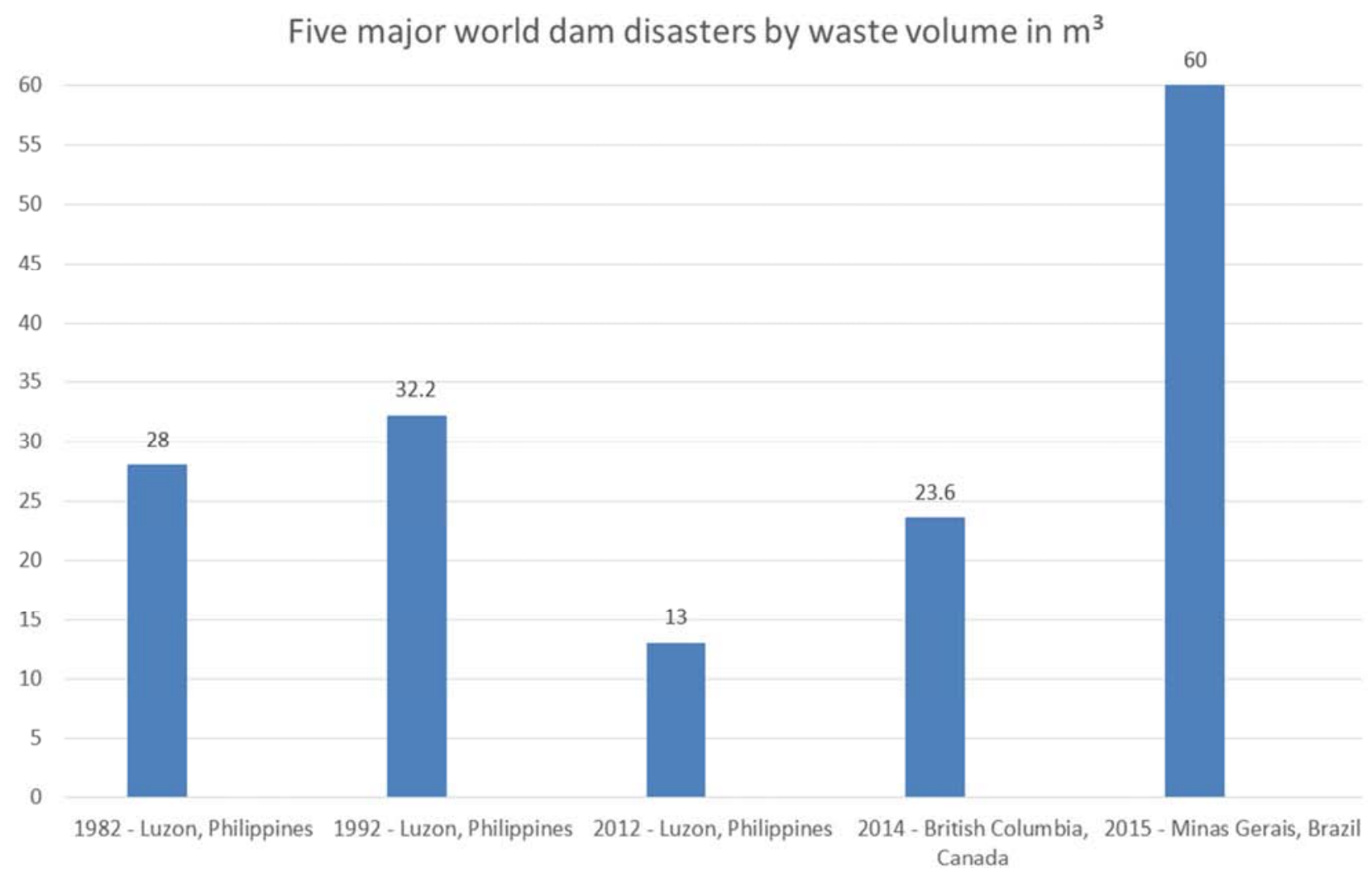

Figure 1. Five major world dam disasters by waste volume [3].

Five major world dam disasters by distance traveled by waste in $\mathrm{km}$

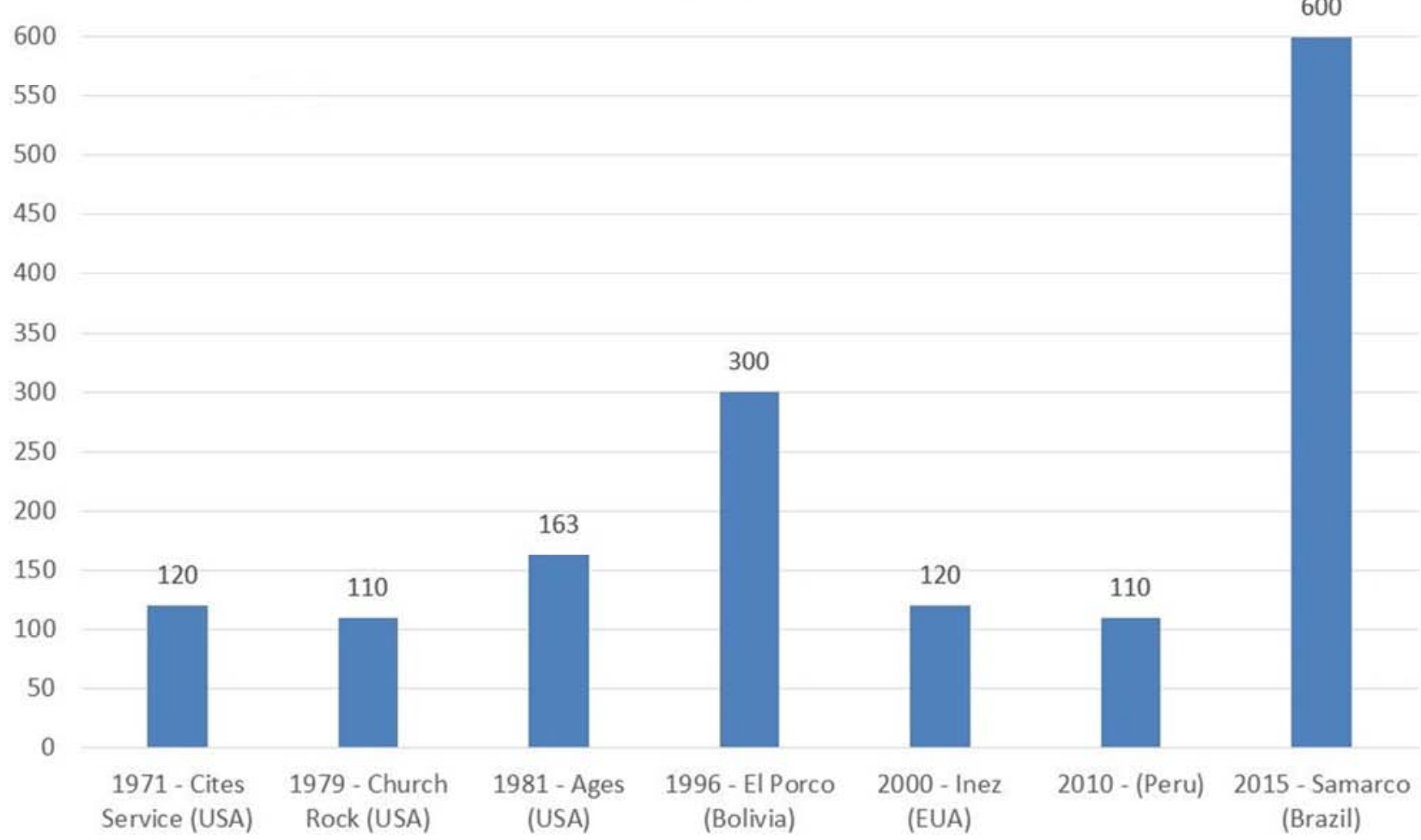

Figure 2. Five major world dam disasters by distance traveled by waste [3]. 


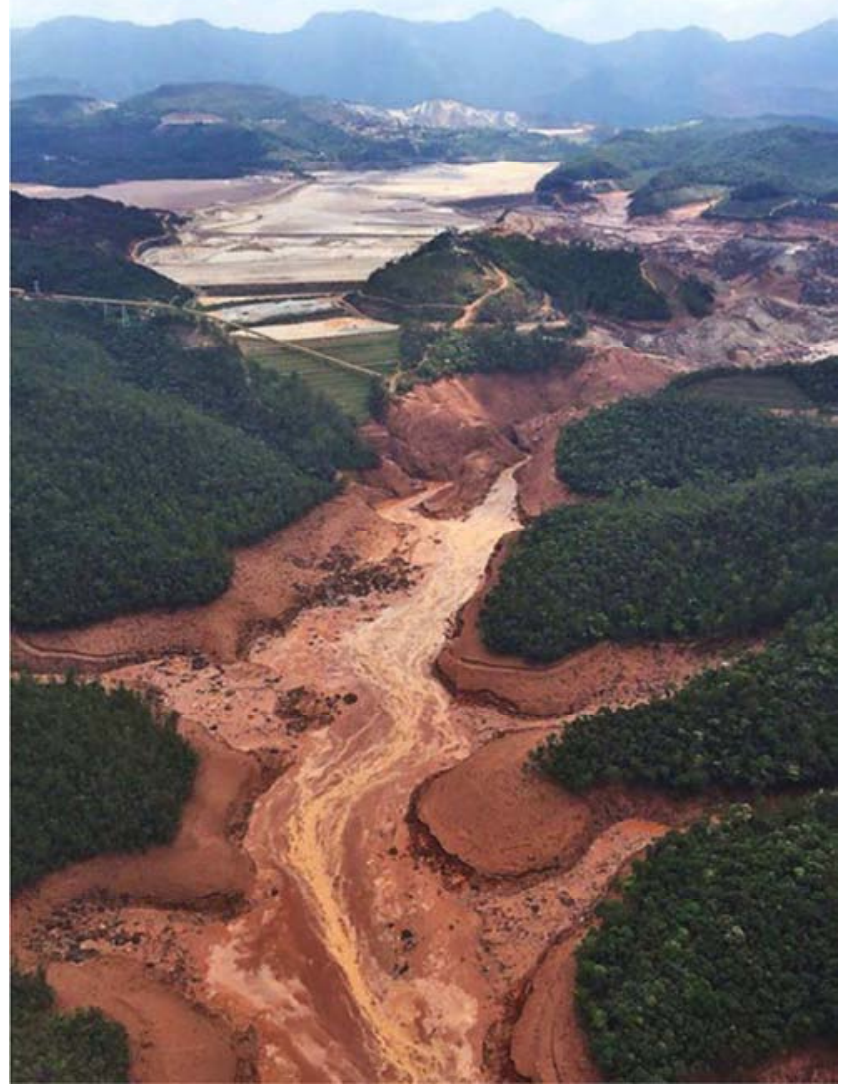

Figure 3. Fundão dam former site immediately after failure [2].

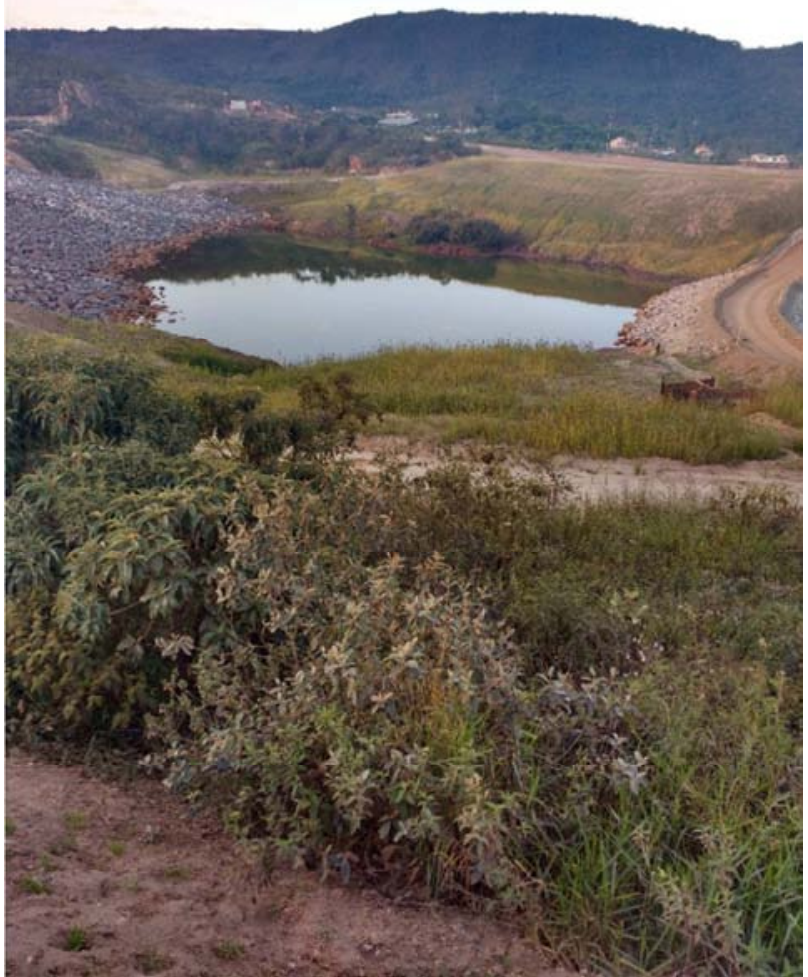

Figure 4. View of the dam formed to retain the mud - May 2017. Photo by the author Deyse Maymone dos Santos.

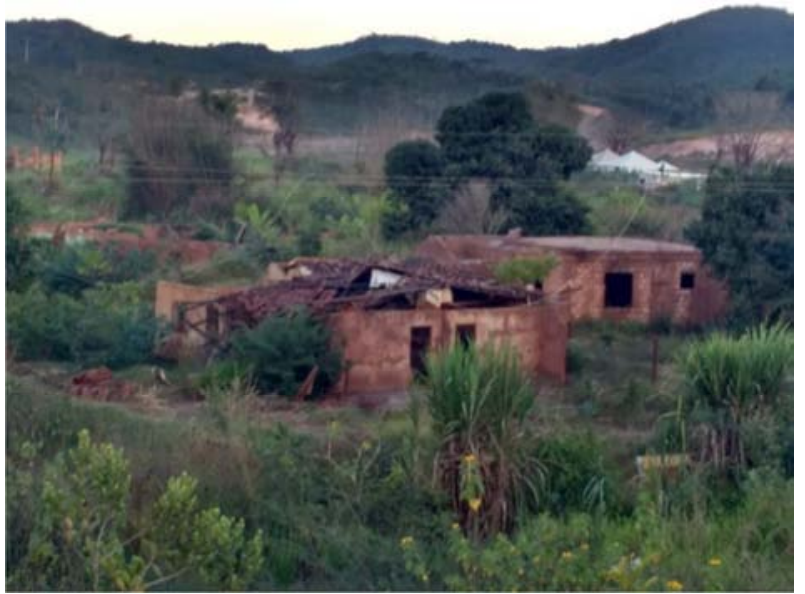

Figure 5. Bento Rodrigues in May 2017. Photo by the author Deyse Maymone dos Santos.

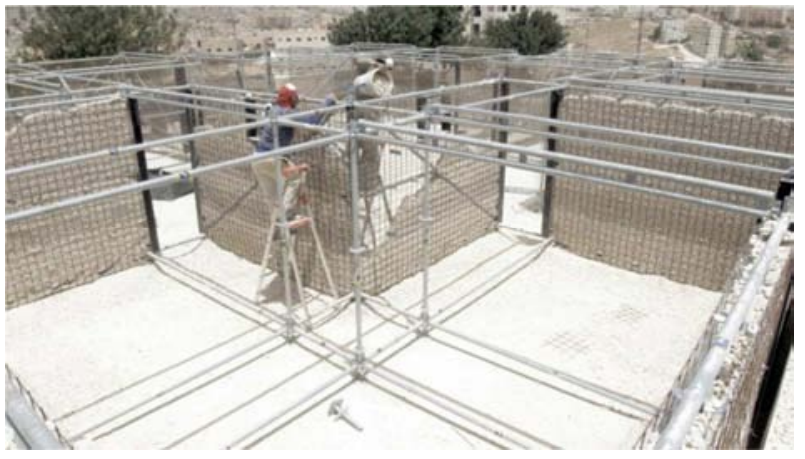

Figure 6. School for refugee children in Jordan, built with scaffolds and sand [1].

\section{Conclusions}

Refugee camps are a different urbanization process and witness the emergence of the peripheral communities here in Brazil - people who are segregated, without access to housing, basic sanitation and health, in a similar way to refugees on the other side of the world. Even with the alarming predictions, Kleinschmidt sees a possibility of reconciling the countries' infrastructure and a dignified life for refugees: rethinking the urban occupation of cities. Refugees can be relocated to areas of low population density where public policies can stimulate trade and work and generate employment and income for the region itself. In short, the future of millions of people around the world depends on two things: solidarity between governments and the recognition of Architecture and Urbanism as powerful agents of social transformation.

\section{References}

[1] Arch Daily. 2015. Available in: http://www.archdaily.com.br/br/771030/escolas-para-criancasrefugiadas-na-jordania-feitas-de-andaimes-e-areia

[2] Bowkers Associates. 2016. Available in: https://indsaynewlandbowker.wordpress.com/2016/02/02/1-m illion-cubic-meter-landslide-from-ruins-of-failed-fundao-dam/ 
[3] EBC. 2016. Available in: http://www.ebc.com.br/noticias/meio-ambiente/2016/01/tragedi a-em-mariana-e-o-maior-acidente-mundial-com-barragens-dos

[4] Freitag, Barbara. Teorias da Cidade. Campinas: Papirus Editora, 2007.

[5] Hometeca. 2016. Available in: https://www.hometeka.com.br/f5/os-campos-de-refugiados-sera o-as-cidades-de-amanha/

[6] IBAMA. Ibama finaliza relatório de vistoria e cobra medidas da Samarco. Available in:

http://www.brasil.gov.br/meio-ambiente/2016/05/ibama-finali za-relatorio-de-vistoria-e-cobra-medidas-da-samarco. Accessed in: 18 may 2017.

[7] IPCC. Intergovernmental Panel on Climate Change. Approved Summary for Policymakers IPCC. Fifth Assessment Synthesis Report. 1 November 2014. Available in: http://www.ipcc.ch/pdf/assessment-report/ar5/syr/SYR_AR5_ SPM.pdf. Accessed in: 10th may 2017.
[8] Machado, Viviane. Lama no Rio Doce: linha do tempo mostra o desastre no Espírito Santo. G 1. 5th may. 2016. Available in: $\mathrm{http}: / / \mathrm{g} 1$.globo.com/espirito-santo/desastre-ambiental-no-rio-d oce/noticia/2016/05/lama-no-rio-doce-linha-do-tempo-mostrao-desastre-no-espirito-santo.html.

[9] SAMARCO. 2016. Available in: http://www.samarco.com/wp-content/uploads/2016/08/06-052016-Reconstrucao-de-Bento-Rodrigues-avanca-com-definica o-de-terreno-para-novo-distrito-acoes-de-recuperacao-tambem -apresentam-resultados-1.pdf

[10] Silva, José Carlos Loureiro. Deslocados pelo meio ambiente. XXIV Encontro Nacional do CONPEDI, Sergipe, Aracaju, Brasil. 2015.

[11] Souza, Daniele Queiroz. Conflito de Competência Cível no Caso Samarco. Trabalho Conclusão Graduação em Direito. Escola de Direito de Brasília - EDB, Brasilia-DF, 2016.

[12] Valencio, Norma (org.). Sociologia dos Desastres - Construção, interfaces e perspectivas no Brasil. Volume II. São Carlos: Ri Ma Editora, 2010. 248 p. il. 